the Helladic settlement at Pelikáta, which Leake and others have identified with the home of Odysseus as described by Homer. Pelikáta is a hill or spur linked on one side with the central peak of the island, and sloping down to the sea in a series of terraces on its three other sides. Thus commanding three bays, and having a flat top, it was, as Mr. Heurtley points out, an admirable site for a primitive community interested in trade or piracy or both. Virtually no trace of buildings remained when investigation began; but there were vestiges of the wall which had enclosed the promontory. Excavations on the site yielded evidence of an early Helladic settlement, which on the evidence of the pottery, Mr. Heurtley concludes, reached the island in Early Helladic II from Corinthia, and afterwards received an accession in a new element in the population, which Minyan ware indicates to have come from the south of Thessaly as its immediate place of origin, with an ultimate derivation from Bronze Age Macedonia.

THE date of the original occupation of Pelikáta is placed at about 2200 B.c. the settlement then being a simple affair-a wall of rough stone blocks surrounding a group of houses with rubble walls and roofs of reeds daubed with mud, situated on top of the hill. These people buried their dead, or rather the bones of their dead in pithoi or jars, which, possibly, were placed below the floors of the houses. The settlement came to an end at about the time which tradition assigns to the Trojan wars, and thus, Mr. Heurtley remarks, those who hold on other grounds that Pelikáta is to be identified as the site of the palace of Odysseus now have some archæological evidence to support their contention. A cave containing stratified deposits on the north-east of the bay of Polis was excavated by Miss Sylvia Benton, and showed evidence of occupation from preMycenæan times to the first century A.D. It was a shrine at which various deities were worshipped, but its local importance seems to have been due to a connexion with Odysseus, for which there is evidence in an inscription on a female mask.

\section{Garden Plants of Proved Excellence}

THE Council of the Royal Horticultural Society established, in 1922, an Award of Garden Merit, as a hall-mark upon the horticultural worth, hardiness and beauty of particular plants. Notes and descriptions of species which have attained to this particular quality have been published from time to time in the Society's Journal; but it was a welcome decision of the Council to publish the collected awards during the past fifteen years in a separate volume ("Some Good Garden Plants", by F. J. Chittenden. London: from the Society's Offices, Vincent Square S.W.1. 1938. 4s. net). The plants described therein have mostly been grown in the Royal Horticultural Society's gardens at Wisley, and are all well known to the Garden Committee. A horticultural description, cultural notes, and suggestions for suitable garden grouping, are appended for each of the 225 species or varieties, and the most suitable soil types are mentioned. References are also given to plates in the Botanical Magazine, when the plant has been so figured. Some kinds, as Lilium regale, Dicentra spectabilis, Primula denticulata, Daphne mezereum and Clematis montana are already well established in favour : other species have recently been introduced to culture from plant-collecting expeditions, whilst yet others are improvements of very common plants. Ulex europaeus flore pleno is a double variety of the common gorse, Caltha palustris plena is a dignified form of the wild marsh marigold, and three improved varieties of the common lilac are described. An alphabetical arrangement assists quick reference, whilst an index divided into annuals, bulbous plants, herbaceous perennials, rock plants, shrubs, small trees, wall and climbing plants, and water plants, enables the gardener to find his way easily among these aristocrats of the garden.

\section{Child Psychology for Parents}

WE have received a copy of an address delivered recently to the parents' association of a school well known for its pioneer work in the field of organized practical training for citizenship. The address is noteworthy if only as a too rare example of effort towards parent-teacher co-operation. The author, Dr. Oswald Schwarz, sought to demonstrate what he described as one of the greatest discoveries of modern psychology-that the foundations of happiness in later life as well as of all troubles, difficulties, problems and abnormalities, are almost invariably laid in the first few years of our childhood. The only real problem in education is, he holds, the problem of an aim in life and its solution is to be sought in evoking and fostering an attitude of respect, or "the appreciation of the inherent value of everything existing just because it exists". He shares, apparently, with Whitehead the notion of actuality as in its essence a process, involving, on the mental side a weaving of reception and anticipation into an end to which its indwelling Eros urges the soul as to the realization of ideal perfection. To the objection that such philosophical ideas do not work with children he answers that he knows "from fairly wide personal experience that most boys from the age of sixteen years onwards are not only able to conceive these ideas but that they grasp them eagerly as if they had long waited for them"; which accords with Whitehead's "youth is peculiarly liable to the vision of that Peace which is the harmony of the soul's activities with ideal aims that lie beyond any personal satisfaction"

\section{The Brotherton Collection of the University of Leeds}

THE second annual report of the Brotherton Collection Committee refers to the considerable interest in the Brotherton Collection which is available for the use of the University of Leeds staff, students, research scholars and the public. The numerous exhibitions which have been arranged, including technical exhibitions for the Process Blockmakers' Society, Printers' Guild, the Technical Institute, and the Society of Chemical Industry, have attracted some 2,300 visitors. Detail work such as 